\title{
Methylobacterium gossipiicola sp. nov., a pink- pigmented, facultatively methylotrophic bacterium isolated from the cotton phyllosphere
}

\author{
Correspondence \\ Munusamy Madhaiyan \\ mmadhaiyan@hotmail.com
}

\author{
Munusamy Madhaiyan, ${ }^{1,2}$ Selvaraj Poonguzhali, ${ }^{1}$ \\ Murugaiyan Senthilkumar, ${ }^{1}$ Jung-Sook Lee ${ }^{3}$ and Keun-Chul Lee ${ }^{3}$ \\ ${ }^{1}$ Department of Agricultural Microbiology, Tamilnadu Agricultural University, Coimbatore 641003 , \\ Tamilnadu, India \\ ${ }^{2}$ Temasek LifeSciences Laboratory, 1 Research Link, NUS, Singapore 117604 \\ ${ }^{3}$ Korean Collection for Type Cultures, Biological Resource Center, Korea Research Institute of \\ Bioscience and Biotechnology, 111 Gwahangno, Yusong-gu, Daejeon 305-806, Republic of \\ Korea
}

\begin{abstract}
A pink, aerobic, facultatively methylotrophic, motile, Gram-negative rod, designated $\mathrm{Gh}-105^{\top}$, was isolated from the phyllosphere of cotton from Coimbatore (Tamilnadu, India). 16S rRNA gene sequence analysis showed clearly that the isolate belonged to the Methylobacterium cluster. Strain Gh-105 ${ }^{\top}$ was most closely related to Methylobacterium adhaesivum AR2 $7^{\top}$ (99\% $16 \mathrm{~S}$ rRNA gene sequence similarity) and Methylobacterium iners $5317 \mathrm{~S}-33^{\top}(97.5 \%)$. The isolate grew with $\mathrm{C}_{1}$ compounds such as methanol and dichloromethane, but not with formaldehyde, formate, methylamine, trimethylamine or methane, as sole carbon sources and carried mxaF, which encodes methanol dehydrogenase and supports methylotrophic metabolism. The major fatty acid was $C_{18: 1} \omega 7 c$ and the $G+C$ content of the genomic DNA was $64.2 \mathrm{~mol} \%$. Physiological and biochemical data and DNA-DNA relatedness with $M$. adhaesivum KACC $12195^{\top}$ and $M$. iners $\mathrm{KACC} 11765^{\top}$ revealed clear phenotypic and genotypic differences. For this reason, we propose that strain $\mathrm{Gh}-105^{\top}\left(=\mathrm{CCM} 7572^{\top}=\mathrm{NRRL} B-51692^{\top}\right)$ represents the type strain of a novel species, with the name Methylobacterium gossipiicola sp. nov.
\end{abstract}

The genus Methylobacterium is a group of strictly aerobic, Gram-negative, rod-shaped, pink-pigmented, facultatively methylotrophic bacteria that can grow on $\mathrm{C}_{1}$ compounds such as methanol and other reduced $\mathrm{C}_{1}$ compounds via the serine pathway (Green, 1992). Molecular taxonomy has classified the genus Methylobacterium as representing a line of descent in the $\alpha 2$ subgroup of the Proteobacteria. At the time of writing, the genus consisted of 34 species with validly published names (http://www.bacterio.cict.fr/m/ methylobacterium.html), with Methylobacterium organophilum as the type species (Patt et al., 1976). Members of the genus Methylobacterium are ubiquitous and are found in soil, dust, fresh water and lake sediment as well as on solid surfaces. They are commonly found in association with plants, and it has been hypothesized that they dominate the phyllosphere bacterial population (Corpe \& Rheem, 1989). Their association with plants varies from

The GenBank/EMBL/DDBJ accession numbers for the 16S rRNA gene and $m x a F$ sequences of strain $\mathrm{Gh}-105^{\top}$ are EU912445 and HO588892, respectively.

Two supplementary figures and two supplementary tables are available with the online version of this paper. strong (symbiotic) to loose (epiphytic) (Pirttilä et al., 2000; Sy et al., 2001; Kutschera, 2007; Schauer \& Kutschera, 2008), a range that also includes intermediate associations (Lacava et al., 2004), and their presence has also been detected using cultivation-independent methods (Araújo et al., 2002; Idris et al., 2004; Jackson et al., 2006). Movements of methylobacteria within the plant as well as inter- and intracellular colonization of plant tissues are well documented (Pirttilä et al., 2000; Sy et al., 2005; Poonguzhali et al., 2008). As phytosymbionts, methylobacteria utilize the methanol released from plants that is a by-product of cell-wall metabolism and emitted through stomatal pores (Nemecek-Marshall et al., 1995; Hüve et al., 2007). In turn, methylobacteria impart a range of beneficial effects on plant growth and development through various mechanisms (Basile et al., 1985; Koenig et al., 2002; Trotsenko et al., 2001; Holland \& Polacco, 1992; Madhaiyan et al., 2006, 2007a, b; Idris et al., 2004). Recent studies have described the ubiquitous presence of methylobacteria on plant surfaces, including Methylobacterium phyllosphaerae, M. mesophilicum and M. platani from leaf phyllospheres (Green \& Bousfield, 1983; Kang et al., 2007; Madhaiyan et al., 2009). 
Strain Gh $-105^{\mathrm{T}}$ was isolated by the leaf imprinting method (Chanprame et al., 1996) from the phylloplane of cotton (Gossipium hirsutum L. 'MCU12') collected from Tamilnadu Agriculture University, Cotton Research Station, Coimbatore, Tamilnadu, India, on selective ammonium mineral salts (AMS) agar (Whittenbury et al., 1970) supplemented with filter-sterilized $10 \mu \mathrm{g}$ cycloheximide $\mathrm{ml}^{-1}$ and $0.5 \%$ $(\mathrm{v} / \mathrm{v})$ methanol at $28{ }^{\circ} \mathrm{C}$. The isolate was preserved at $-80{ }^{\circ} \mathrm{C}$ in nutrient broth (Difco) with $1 \%$ methanol (v/v), in AMS broth with $0.5 \%$ methanol and $50 \%$ glycerol $(\mathrm{v} / \mathrm{v})$ or by lyophilization. Morphological and phenotypic characteristics were studied according to the standard protocols described by Gerhardt et al. (1994) and Green \& Bousfield (1982). The Gram-stain reaction was determined using a Gram-staining kit (Difco), according to the manufacturer's instructions. Cell morphology was observed at $\times 1000$ magnification with a light microscope (Nikon) using cells grown for $72 \mathrm{~h}$ at $30{ }^{\circ} \mathrm{C}$ on AMS agar. Catalase activity was determined by assessing bubble production with $3 \%(\mathrm{v} / \mathrm{v})$ $\mathrm{H}_{2} \mathrm{O}_{2}$ and oxidase activity was determined using $1 \%(\mathrm{w} / \mathrm{v})$ tetramethyl-p-phenylenediamine using BBL catalase and oxidase reagent droppers (Difco), according to the manufacturer's instructions. Motility was tested in 1/10 R2A broth (Difco) supplemented with $0.2 \%$ agar. Indole production was tested on MIL medium (Difco), according to the manufacturer's instructions. Anaerobic growth was tested by incubating cultures on R2A agar in a GasPak jar (BBL) for 14 days; aerobically incubated plates were used as controls. Growth at $5-45{ }^{\circ} \mathrm{C}$ and $\mathrm{pH} 4-10$ (at intervals of $1 \mathrm{pH}$ unit) was monitored in R2A broth. Growth with $0,2,3,5$ and $7 \%$ $(\mathrm{w} / \mathrm{v}) \mathrm{NaCl}$ was tested in $\mathrm{R} 2 \mathrm{~A}$ broth. Other physiological and biochemical characteristics were tested using the API ZYM, API 20 NE and API 32 GN galleries (bioMérieux), according to the manufacturer's instructions. Nutritional characteristics were determined using GN2 MicroPlates (Biolog), as described previously (Madhaiyan et al., 2007c). Utilization of other carbon sources not included in the MicroPlates was determined as described by Green \& Bousfield (1982). Methanol, dichloromethane, methylamine, dimethylamine, trimethylamine and formaldehyde were added to minimal medium to concentrations of 0.2 and $0.5 \%(\mathrm{v} / \mathrm{v})$ and results were recorded after incubation for 14 days at $30{ }^{\circ} \mathrm{C}$ (Doronina et al., 2000; Green \& Bousfield, 1982). Scanning electron microscopy was performed on material that was prepared for routine examinations, as described by Bozzola \& Russell (1998). Samples were critical point-dried, mounted on stubs, sputter-coated with gold/palladium and visualized using a Hitachi S-2500C microscope with a GEMINI column equipped with a field-emission electron source. 1-Aminocyclopropane-1-carboxylate deaminase activity was determined by plate and quantitative assays, as described previously (Madhaiyan et al., 2006).

Cells of strain Gh- $105^{\mathrm{T}}$ were Gram-negative, aerobic, nonendospore-forming motile rods, were frequently branched and occurred singly or in rosettes after growth on AMS agar (Supplementary Fig. S1, available in IJSEM Online). Colonies were light pink. Strain Gh-105 ${ }^{\mathrm{T}}$ grew on NA,
R2A, PYG, succinate, glycerol peptone and plate-count agar media and did not grow on MacConkey agar. Strain Gh$105^{\mathrm{T}}$ utilized $\mathrm{C}_{1}$ substrates such as methanol and dichloromethane, but did not utilize methylamine, dimethylamine, trimethylamine or formaldehyde. Characteristics that differentiate strain $\mathrm{Gh}-105^{\mathrm{T}}$ from its closest relatives are summarized in Table 1 and Supplementary Table S1.

The 16S rRNA gene sequence was determined as described by Madhaiyan et al. (2009). Multiple sequence alignment and data analysis were performed using MEGA version 4 (Tamura et al., 2007). Genetic distance calculations used the distance options according to the Kimura-2 model. Clustering was performed using the neighbour-joining (Fig. 1) and maximum-parsimony (not shown) methods and bootstrap values were calculated on the basis of 1000 replications. Pairwise comparisons were performed using the EzTaxon program (Chun et al., 2007). The 16S rRNA gene sequence of strain Gh- $105^{\mathrm{T}}$ obtained in this study was a continuous stretch of $1351 \mathrm{bp}$. Strain Gh-105 ${ }^{\mathrm{T}}$ showed $99 \%$ 16S rRNA gene sequence similarity with Methylobacterium adhaesivum $\mathrm{AR} 27^{\mathrm{T}}$ and $97.5 \%$ with Methylobacterium iners $5317 \mathrm{~S}-33^{\mathrm{T}}$. Sequence similarities with all other members of the genus Methylobacterium were $<97.0 \%$. In the neighbour-joining phylogenetic tree (Fig. 1), strain Gh- $105^{\mathrm{T}}$ clustered with $M$. adhaesivum $\mathrm{AR} 27^{\mathrm{T}}$ and $M$. iners 5317S$33^{\mathrm{T}}$ but formed a separate line of descent within this cluster.

The methanol dehydrogenase gene ( $m x a F)$, which is required for methanol utilization, was amplified from extracted DNA using the primer pair mxaF f1003 (5'-GCGGCACCAACTGGGGCTGGT-3') and mxaF r1561 (5'-GGGCAGCATGAAGGGCTCCC-3') (McDonald \& Murrell, 1997). The mxaF sequence from strain Gh- $105^{\mathrm{T}}$ obtained in this study was a continuous stretch of $541 \mathrm{bp}$. Strain Gh- $105^{\mathrm{T}}$ showed $98 \%$ $m x a F$ sequence similarity with $M$. adhaesivum $\mathrm{AR} 27^{\mathrm{T}}$ and $M$. iners KACC $11765^{\mathrm{T}}$. In the neighbour-joining phylogenetic tree based on mxaF sequences (Supplementary Fig. S2), strain Gh $-105^{\mathrm{T}}$ formed a separate line in the cluster containing $M$. adhaesivum $\mathrm{AR} 27^{\mathrm{T}}$.

Cellular fatty acids of cells grown on NA with $1 \%$ methanol $(\mathrm{v} / \mathrm{v})$ at $28{ }^{\circ} \mathrm{C}$ for $48 \mathrm{~h}$ were analysed according to the standard protocol of the MIDI/Hewlett Packard Microbial Identification System (Sasser, 1990) with the TSBA6 database and Sherlock version 6.0 (Microbial ID). The $\mathrm{G}+\mathrm{C}$ content of genomic DNA was determined by reversed-phase HPLC (Supelcosil LC-18 S; Supelco) of individual nucleosides, as described by Mesbah et al. (1989). DNA-DNA hybridization was carried out as described by Seldin \& Dubnau (1985). Probe labelling was conducted using the non-radioactive DIG High Prime DNA Labelling and Detection Starter Kit II (Roche Diagnostics). Hybridized DNA was visualized using the DIG Luminescent Detection Kit (Roche Molecular Biochemicals) and DNA-DNA relatedness was quantified using a densitometer (Bio-Rad Laboratories). Cell biomass for quinone analysis was obtained from cultivation in R2A agar at $28{ }^{\circ} \mathrm{C}$ for 10 days. The isoprenoid quinone was 
Table 1. Differential characteristics of strain $\mathrm{Gh}-105^{\top}$ and some members of the genus Methylobacterium

Strains: 1, Methylobacterium gossipiicola sp. nov. Gh-105 ${ }^{\mathrm{T}}$; 2, M. adhaesivum KACC $12195^{\mathrm{T}} ; 3$, M. mesophilicum DSM 1708 ${ }^{\mathrm{T}}$; 4, M. phyllosphaerae $\mathrm{CBMB}^{\mathrm{T}}{ }^{\mathrm{T}}$; 5, M. oryzae CBMB20 ${ }^{\mathrm{T}}$; 6, M. fujisawaense KACC $10744^{\mathrm{T}}$; 7, M. organophilum DSM 760 ${ }^{\mathrm{T}}$; 8, M. radiotolerans DSM $1819^{\mathrm{T}}$; 9 , M. extorquens DSM $1337^{\mathrm{T}}$; 10, M. hispanicum DSM $16372^{\mathrm{T}}$; 11, M. iners KACC $11765^{\mathrm{T}}$ (data from Weon et al., 2008); 12, M. aerolatum KACC $11766^{\mathrm{T}}$ (Weon et al., 2008); 13, M. platani KCTC $12901^{\mathrm{T}}$ (Kang et al., 2007). Data were obtained in this study unless indicated. All strains grow on methanol and have singly occurring cells. +, Positive; w, weakly positive; -, negative; ND, no data available.

\begin{tabular}{|c|c|c|c|c|c|c|c|c|c|c|c|c|c|}
\hline Characteristic & 1 & 2 & 3 & 4 & 5 & 6 & 7 & 8 & 9 & 10 & 11 & 12 & 13 \\
\hline Colony diameter $(\mathrm{mm})$ & $0.4-1.3$ & $0.5-0.8$ & $0.4-1.4$ & $0.2-0.8$ & $0.8-1.7$ & $0.8-1.2$ & $1.0-1.6$ & $0.7-1.5$ & $0.6-1.7$ & $1.0-2.0$ & $0.4-0.7$ & $0.5-0.8$ & $0.5-1.8$ \\
\hline Colony pigmentation ${ }^{\star}$ & LP & $\mathrm{P}$ & WP & $\mathrm{P}$ to $\mathrm{R}$ & $\mathrm{P}$ to $\mathrm{R}$ & $\mathrm{P}$ & LP & $\mathrm{P}$ to $\mathrm{R}$ & $\mathrm{P}$ & LP & $\mathrm{P}$ & $\mathrm{P}$ & $\mathrm{P}$ \\
\hline \multicolumn{14}{|l|}{ Cell characteristics } \\
\hline Pairs & + & Rare & + & + & + & Rare & Rare & Rare & + & + & Rare & Rare & + \\
\hline Rosettes & + & + & + & + & + & + & - & + & - & + & - & - & + \\
\hline Length $(\mu \mathrm{m})$ & $1.4-2.2$ & $1.5-5$ & $2.3-4.4$ & $1.8-2.7$ & $2.1-2.8$ & ND & $\mathrm{ND}$ & $1.4-2.5$ & $2-2.5$ & $2-2.5$ & $1.5-2.5$ & $1.5-3$ & $2.0-6.5$ \\
\hline Width $(\mu \mathrm{m})$ & $0.4-0.5$ & $1.0-1.2$ & $1-2.2$ & 0.6 & $0.6-0.8$ & $\mathrm{ND}$ & $\mathrm{ND}$ & $0.6-0.8$ & $1-1.5$ & $1-1.5$ & 1.0 & 1.0 & $1.4-1.5$ \\
\hline \multicolumn{14}{|l|}{ Conditions for growth } \\
\hline Maximum $\mathrm{NaCl}(\%)$ & 1.5 & 1 & 1 & 1 & 1.5 & 1 & 1.5 & $<2$ & $<2$ & $<1$ & $<2$ & $<2$ & 1 \\
\hline $\begin{array}{l}\text { Optimum temperature } \\
\left({ }^{\circ} \mathrm{C}\right)\end{array}$ & 28 & 28 & 30 & 28 & 28 & 28 & $25-30$ & $20-32$ & 30 & 28 & $25-28$ & 28 & $25-30$ \\
\hline $\mathrm{pH}$ range & $5-8$ & $5-9$ & $6-8$ & $5-9$ & $5-10$ & $6-8$ & $5-8$ & $6-8$ & $5-9$ & $5-8$ & $6-8$ & $5-9$ & $6-8$ \\
\hline Nitrate reduction & - & - & - & - & + & - & - & + & - & - & - & - & + \\
\hline Oxidase & + & $+/ \mathrm{w}$ & $+/ \mathrm{w}$ & + & + & - & $+/ \mathrm{w}$ & + & + & + & + & + & + \\
\hline Urease & + & + & - & + & - & - & - & - & + & + & - & + & + \\
\hline Gelatin hydrolysis & - & - & - & - & - & - & - & - & - & - & + & - & - \\
\hline \multicolumn{14}{|l|}{ Utilization of: } \\
\hline L-Arabinose & + & - & + & + & + & + & - & + & - & - & - & w & + \\
\hline L-Glutamate & + & + & + & + & + & + & + & + & + & + & + & - & - \\
\hline Citrate & + & + & + & + & - & + & - & + & - & + & - & - & - \\
\hline D-Fucose & - & - & + & + & - & + & - & + & - & - & - & - & - \\
\hline D-Fructose & $\mathrm{W}$ & + & - & + & - & - & + & - & - & - & - & - & + \\
\hline D-Glucose & + & - & + & $\mathrm{w}$ & - & + & - & + & - & - & - & w & - \\
\hline Acetate & + & + & - & $\mathrm{W}$ & - & + & + & + & + & + & + & - & + \\
\hline L-Aspartate & - & - & + & + & - & + & + & - & - & + & + & - & + \\
\hline $\begin{array}{l}\text { DNA G }+\mathrm{C} \text { content } \\
(\mathrm{mol} \%) \dagger\end{array}$ & 64.2 & 63.6 & 69.5 & 66.8 & 70.6 & 69.9 & 70.5 & 71.2 & 68.2 & 67.7 & 68.0 & 73.2 & 68.5 \\
\hline
\end{tabular}

${ }^{*}$ LP, Light pink; P, pink; R, red; WP, whitish pink.

$\nmid$ Data for reference strains from Madhaiyan et al. (2007c, 2009), Gallego et al. (2006) and Urakami et al. (1993).

investigated using reversed-phase HPLC, as described by Komagata \& Suzuki (1987). The fatty acids of strain Gh$105^{\mathrm{T}}$ consisted mainly of $\mathrm{C}_{18: 1} \omega 7 c$, summed feature 3 (comprising $\mathrm{C}_{16: 1} \omega 7 c$ and/or $\mathrm{C}_{16: 1} \omega 6 c$ ) and $\mathrm{C}_{16: 0}$ (Supplementary Table S2). The DNA G $+\mathrm{C}$ content of strain Gh- $105^{\mathrm{T}}$ was $64.2 \mathrm{~mol} \%$, which falls within the range described for the genus Methylobacterium (Green, 1992) (Table 1). Strain Gh- $105^{\mathrm{T}}$ showed low DNA-DNA relatedness with $M$. adhaesivum KACC $12195^{\mathrm{T}}(52.1 \pm 3.1 \%)$ and $M$. iners KACC $11765^{\mathrm{T}}(15.1 \pm 1.9 \%)$. When the recommendation of a threshold value of $70 \%$ DNA-DNA relatedness for the definition of species is considered (Wayne et al., 1987), this result indicates that strain Gh$105^{\mathrm{T}}$ does not belong to M. adhaesivum or M. iners.

16S rRNA gene sequence similarity, DNA-DNA relatedness and phenotypic characteristics allowed the separation of strain Gh- $105^{\mathrm{T}}$ from other members of the genus
Methylobacterium. Therefore, strain Gh- $105^{\mathrm{T}}$ represents a novel species of Methylobacterium, for which the name Methylobacterium gossipiicola sp. nov. is proposed.

\section{Description of Methylobacterium gossipiicola sp. nov.}

Methylobacterium gossipiicola (gos.si.pi.i'co.la. N.L. n. Gossipium a scientific botanical genus name; L. suff. -cola inhabitant, dweller; N.L. n. gossipiicola Gossipium dweller, referring to the isolation of the type strain from the cotton phyllosphere).

Gram-negative, non-endospore-forming, strictly aerobic, motile rods $(0.4-0.5 \times 1.4-2.2 \mu \mathrm{m})$, occurring singly, in pairs or in rosettes. On AMS agar at $28{ }^{\circ} \mathrm{C}$, colonies are light pink, convex, translucent with regular edges and slow growing $(0.4-1.3 \mathrm{~mm}$ in diameter after $96 \mathrm{~h})$. Grows on NA, R2A, PYG, succinate, glycerol peptone and plate-count 


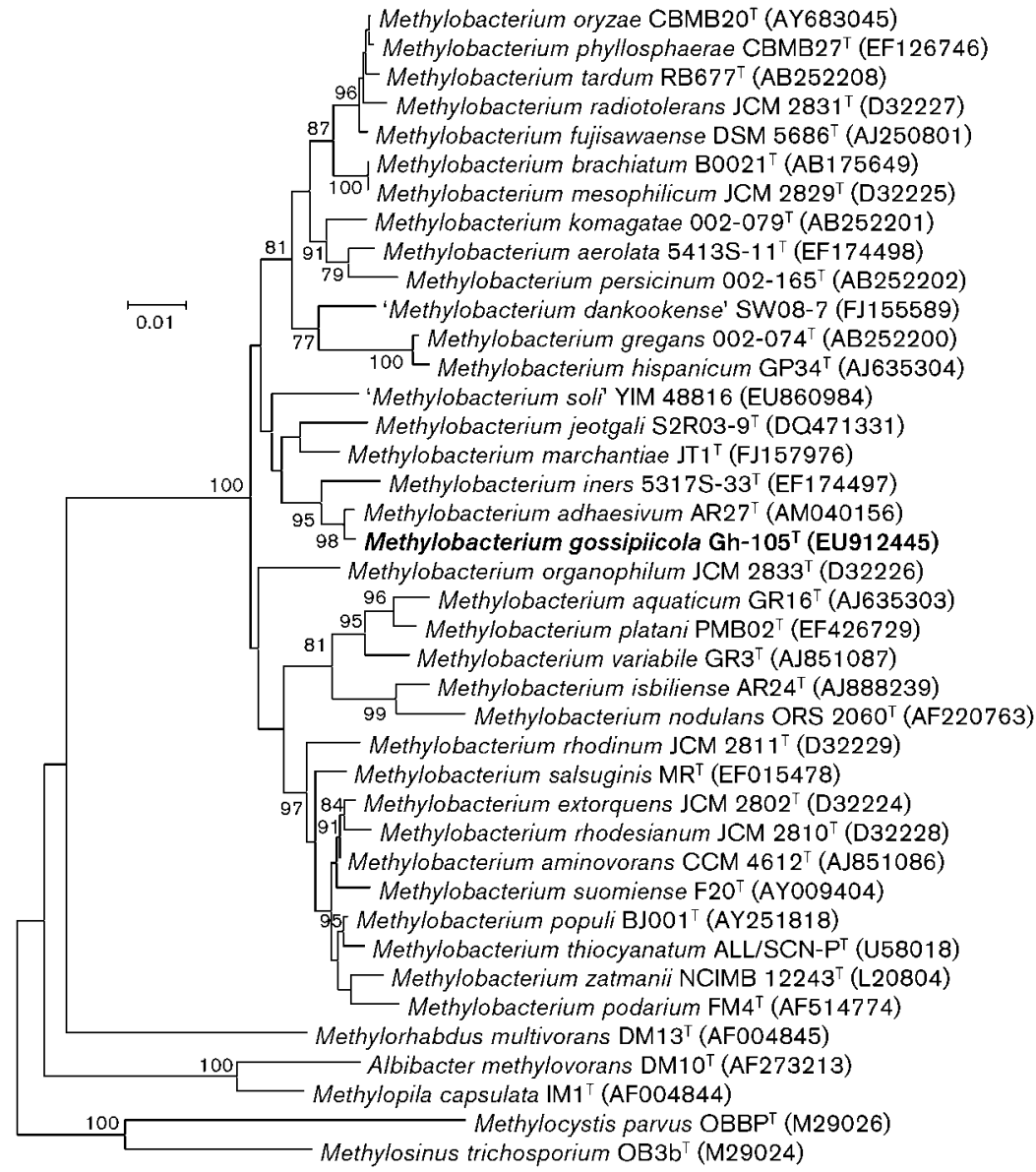

Fig. 1. Neighbour-joining phylogenetic tree based on 16S rRNA gene sequences showing the position of strain $\mathrm{Gh}-105^{\top}$ in the genus Methylobacterium. Bootstrap values ( $>70 \%$ ) based on 1000 replications are shown at branch nodes. Bar, $0.01 \%$ nucleotide sequence divergence. agar media. Does not grow in the presence of $\geqslant 2 \% \mathrm{NaCl}$. Grows at $20-30{ }^{\circ} \mathrm{C}$ (optimum $28{ }^{\circ} \mathrm{C}$ ) and at $\mathrm{pH}$ 5.0-9.0 (optimum $\mathrm{pH}$ 6.8). Catalase, oxidase, arginine dihydrolase and urease are present, but pectinase, cellulase, protease and $\beta$-galactosidase are absent. Nitrate reduction, glucose fermentation, indole production and methyl red and VogesProskauer tests are negative. Gelatin, starch, glycerol tributyrate, casein and aesculin are not hydrolysed. Hydrogen sulfide is not produced. Simmons' citrate test is positive. As sole nitrogen sources, ammonium sulfate, potassium nitrate, sodium nitrate, ammonium chloride, L-alanine, L-tryptophan, urea, 1-aminocyclopropane 1-carboxylate and potassium thiocyanate are utilized, but methylamine, trimethylamine, glycine, potassium cyanate, diphenylamine and diethylamine are not utilized. As sole carbon and energy sources (MicroPlate), dextrin, glycogen, L-arabinose, cellobiose, Dfructose, D-galactose, $\alpha$-D-glucose, lactulose, D-mannitol, Dmannose, D-psicose, D-sorbitol, sucrose, trehalose, turanose, pyruvic acid methyl ester, succinic acid monomethyl ester, acetic acid, cis-aconitic acid, citric acid, formic acid, Dgluconic acid, D-glucuronic acid, $\alpha$-, $\beta$ - and $\gamma$-hydroxybutyric acids, $\alpha$-ketobutyric acid, $\alpha$-ketoglutaric acid, $\alpha$-ketovaleric acid, DL-lactic acid, propionic acid, quinic acid, D-saccharic acid, sebacic acid, succinic acid, bromosuccinic acid, succinamic acid, glucuronamide, L-alanine, L-alanyl glycine, Lglutamic acid, glycyl L-aspartic acid, L-leucine, L-serine,
L-threonine, DL-carnitine, $\gamma$-aminobutyric acid, glycerol, DL$\alpha$-glycerol phosphate, $\alpha$-D-glucose 1 -phosphate and D-glucose 6-phosphate are utilized. With API ZYM, esterase (C4), esterase lipase (C8), leucine arylamidase, trypsin, alkaline phosphatase and naphthol-AS-BI-phosphohydrolase are present, but acid phosphatase, lipase (C14), valine arylamidase, cystine arylamidase, $\alpha$-chymotrypsin, $\alpha$ - and $\beta$-galactosidases, $\beta$-glucuronidase, $\alpha$ - and $\beta$-glucosidases, $N$-acetyl- $\beta$-glucosaminidase, $\alpha$-mannosidase and $\alpha$-fucosidase are absent. The major isoprenoid quinone is Q-10. The major fatty acids are $\mathrm{C}_{18: 1} \omega 7 c$ and summed feature 3 (comprising $\mathrm{C}_{16: 1} \omega 7 c$ and/or $\left.\mathrm{C}_{16: 1} \omega 6 c\right)$. The DNA $\mathrm{G}+\mathrm{C}$ content of the type strain is $64.2 \mathrm{~mol} \%$.

The type strain, Gh- $105^{\mathrm{T}}\left(=\mathrm{CCM} 7572^{\mathrm{T}}=\right.$ NRRL B-51692 ${ }^{\mathrm{T}}$ ), was isolated from the leaf surface of cotton (Gossipium hirsutum L. 'MCU12') collected from Tamilnadu Agriculture University, Cotton Research Station (Coimbatore, Tamilnadu, India).

\section{Acknowledgements}

We wish to thank Dana Novakova, Czech Collection of Microorganisms, Czech Republic, and Alejandro P. Rooney, ARS Culture Collection, National Center for Agricultural Utilization Research, US Department of Agriculture, Peoria, USA, for their valuable advice. We also thank Dr J. P. Euzéby for his advice regarding the species epithet. 


\section{References}

Araújo, W. L., Marcon, J., Maccheroni, W., Jr, Van Elsas, J. D., Van Vuurde, J. W. \& Azevedo, J. L. (2002). Diversity of endophytic bacterial populations and their interaction with Xylella fastidiosa in citrus plants. Appl Environ Microbiol 68, 4906-4914.

Basile, D. V., Basile, M. R., Li, Q. Y. \& Corpe, W. A. (1985). Vitamin B12-stimulated growth and development of Jungermannia leiantha Grolle and Gymnocolea inflata (Huds.) Dum (Hepaticae). Bryologist 88, 77-81.

Bozzola, J. J. \& Russell, L. D. (1998). Electron Microscopy, 2nd edn. Sudbury, MA: Jones \& Bartlett.

Chanprame, S., Todd, J. J. \& Widholm, J. M. (1996). Prevention of pink-pigmented methylotrophic bacteria (Methylobacterium mesophilicum) contamination of plant tissue cultures. Plant Cell Rep 16, 222225.

Chun, J., Lee, J.-H., Jung, Y., Kim, M., Kim, S., Kim, B. K. \& Lim, Y.-W. (2007). EzTaxon: a web-based tool for the identification of prokaryotes based on $16 \mathrm{~S}$ ribosomal RNA gene sequences. Int J Syst Evol Microbiol 57, 2259-2261.

Corpe, W. A. \& Rheem, S. (1989). Ecology of the methylotrophic bacteria on living leaf surfaces. FEMS Microbiol Ecol 62, 243-249.

Doronina, N. V., Trotsenko, Y. A., Tourova, T. P., Kuznetsov, B. B. \& Leisinger, T. (2000). Methylopila helvetica sp. nov. and Methylobacterium dichloromethanicum sp. nov. - novel aerobic facultatively methylotrophic bacteria utilizing dichloromethane. Syst Appl Microbiol 23, 210-218.

Gerhardt, P. R., Murray, R. G. E., Wood, W. A. \& Krieg, N. R. (editors) (1994). Methods for General and Molecular Bacteriology. Washington, DC: American Society for Microbiology.

Green, P. N. (1992). The genus Methylobacterium. In The Prokaryotes, 2nd edn, pp. 2342-2349. Edited by A. Balows, H. G. Trüper, M. Dworkin, W. Harder \& K. H. Schleifer. New York: Springer.

Green, P. N. \& Bousfield, I. J. (1982). A taxonomic study of some Gram-negative facultatively methylotrophic bacteria. J Gen Microbiol 128, 623-638.

Green, P. N. \& Bousfield, I. J. (1983). Emendation of Methylobacterium Patt, Cole, and Hanson 1976; Methylobacterium rhodinum (Heumann 1962) comb. nov. corrig.; Methylobacterium radiotolerans (Ito and Iizuka 1971) comb. nov. corrig.; and Methylobacterium mesophilicum (Austin and Goodfellow 1979) comb. nov. Int J Syst Bacteriol 33, 875-877.

Holland, M. A. \& Polacco, J. C. (1992). Urease-null and hydrogenasenull phenotypes of a phylloplane bacterium reveal altered nickel metabolism in two soybean mutants. Plant Physiol 98, 942-948.

Hüve, K., Christ, M. M., Kleist, E., Uerlings, R., Niinemets, Ü., Walter, A. \& Wildt, J. (2007). Simultaneous growth and emission measurements demonstrate an interactive control of methanol release by leaf expansion and stomata. J Exp Bot 58, 1783-1793.

Idris, R., Trifonova, R., Puschenreiter, M., Wenzel, W. W. \& Sessitsch, A. (2004). Bacterial communities associated with flowering plants of the $\mathrm{Ni}$ hyperaccumulator Thlaspi goesingense. Appl Environ Microbiol 70, 26672677.

Jackson, E. F., Echlin, H. L. \& Jackson, C. R. (2006). Changes in the phyllosphere community of the resurrection fern, Polypodium polypodioides, associated with rainfall and wetting. FEMS Microbiol Ecol 58, 236-246.

Kang, Y.-S., Kim, J.-H., Shin, H.-D., Nam, Y.-D., Bae, J.-W., Jeon, C.-O. \& Park, W.-J. (2007). Methylobacterium platani sp. nov., isolated from a leaf of the tree Platanus orientalis. Int J Syst Evol Microbiol 57, 28492853.
Koenig, R. L., Morris, R. O. \& Polacco, J. C. (2002). tRNA is the source of low-level trans-zeatin production in Methylobacterium spp. J Bacteriol 184, 1832-1842.

Komagata, K. \& Suzuki, K. (1987). Lipid and cell-wall analysis in bacterial systematics. Methods Microbiol 19, 161-207.

Kutschera, U. (2007). Plant-associated methylobacteria as co-evolved phytosymbionts: a hypothesis. Plant Signal Behav 2, 74-78.

Lacava, P. T., Araújo, W. L., Marcon, J., Maccheroni, W., Jr \& Azevedo, J. L. (2004). Interaction between endophytic bacteria from citrus plants and the phytopathogenic bacteria Xylella fastidiosa, causal agent of citrus-variegated chlorosis. Lett Appl Microbiol 39, 55-59.

Madhaiyan, M., Poonguzhali, S., Ryu, J.-H. \& Sa, T.-M. (2006). Regulation of ethylene levels in canola (Brassica campestris) by 1aminocyclopropane-1-carboxylate deaminase-containing Methylobacterium fujisawaense. Planta 224, 268-278.

Madhaiyan, M., Poonguzhali, S. \& Sa, T. M. (2007a). Metal tolerating methylotrophic bacteria reduces nickel and cadmium toxicity and promotes plant growth of tomato (Lycopersicon esculentum L.). Chemosphere 69, 220-228.

Madhaiyan, M., Poonguzhali, S. \& Sa, T. M. (2007b). Characterization of 1-aminocyclopropane-1-carboxylate (ACC) deaminase containing Methylobacterium oryzae and interactions with auxins and ACC regulation of ethylene in canola (Brassica campestris). Planta 226, 867-876.

Madhaiyan, M., Kim, B.-Y., Poonguzhali, S., Kwon, S.-W., Song, M.-H., Ryu, J.-H., Go, S.-J., Koo, B.-S. \& Sa, T.-M. (2007c). Methylobacterium oryzae sp. nov., an aerobic, pink-pigmented, facultatively methylotrophic, 1 -aminocyclopropane-1-carboxylate deaminase-producing bacterium isolated from rice. Int J Syst Evol Microbiol 57, 326-331.

Madhaiyan, M., Poonguzhali, S., Kwon, S.-W. \& Sa, T.-M. (2009). Methylobacterium phyllosphaerae sp. nov., a pink-pigmented, facultative methylotroph from the phyllosphere of rice. Int J Syst Evol Microbiol 59, 22-27.

McDonald, I. R. \& Murrell, J. C. (1997). The methanol dehydrogenase structural gene $m x a F$ and its use as a functional gene probe for methanotrophs and methylotrophs. Appl Environ Microbiol 63, 3218-3224.

Mesbah, M., Premachandran, U. \& Whitman, W. B. (1989). Precise measurement of the $\mathrm{G}+\mathrm{C}$ content of deoxyribonucleic acid by highperformance liquid chromatography. Int J Syst Bacteriol 39, 159-167.

Nemecek-Marshall, M., MacDonald, R. C., Franzen, J. J., Wojciechowski, C. L. \& Fall, R. (1995). Methanol emission from leaves: enzymatic detection of gas-phase methanol and relation of methanol fluxes to stomatal conductance and leaf development. Plant Physiol 108, 1359-1368.

Patt, T. E., Cole, G. C. \& Hanson, R. S. (1976). Methylobacterium, a new genus of facultatively methylotrophic bacteria. Int J Syst Bacteriol 26, 226-229.

Pirttilä, A. M., Laukkanen, H., Pospiech, H., Myllylä, R. \& Hohtola, A. (2000). Detection of intracellular bacteria in the buds of Scotch pine (Pinus sylvestris L.) by in situ hybridization. Appl Environ Microbiol 66, 3073-3077.

Poonguzhali, S., Madhaiyan, M., Yim, W.-J., Kim, K.-A. \& Sa, T.-M. (2008). Colonization pattern of plant root and leaf surfaces visualized by use of green-fluorescent-marked strain of Methylobacterium suomiense and its persistence in rhizosphere. Appl Microbiol Biotechnol 78, 10331043.

Sasser, M. (1990). Identification of bacteria through fatty acid analysis. In Methods in Phytobacteriology, pp. 199-204. Edited by S. Klement, K. Rudolf \& D. Sands. Budapest: Akademiai Kiado.

Schauer, S. \& Kutschera, U. (2008). Methylotrophic bacteria on the surfaces of field-grown sunflower plants: a biogeographic perspective. Theory Biosci 127, 23-29. 
Seldin, L. \& Dubnau, D. (1985). Deoxyribonucleic acid homology among Bacillus polymyxa, Bacillus macerans, Bacillus azotofixans, and other nitrogen-fixing Bacillus strains. Int J Syst Bacteriol 35, 151154.

Sy, A., Giraud, E., Jourand, P., Garcia, N., Willems, A., de Lajudie, P., Prin, Y., Neyra, M., Gillis, M. \& other authors (2001). Methylotrophic Methylobacterium bacteria nodulate and fix nitrogen in symbiosis with legumes. J Bacteriol 183, 214-220.

Sy, A., Timmers, A. C. J., Knief, C. \& Vorholt, J. A. (2005). Methylotrophic metabolism is advantageous for Methylobacterium extorquens during colonization of Medicago truncatula under competitive conditions. Appl Environ Microbiol 71, 7245-7252.

Tamura, K., Dudley, J., Nei, M. \& Kumar, S. (2007). MEGA4: molecular evolutionary genetics analysis (MEGA) software version 4.0. Mol Biol Evol 24, 1596-1599.
Trotsenko, Y. A., Ivanova, E. G. \& Doronina, N. V. (2001). [Aerobic methylotrophic bacteria as phytosymbionts]. Mikrobiologiia 70, 623632 (in Russian).

Wayne, L. G., Brenner, D. J., Colwell, R. R., Grimont, P. A. D., Kandler, O., Krichevsky, M. I., Moore, L. H., Moore, W. E. C., Murray, R. G. E. \& other authors (1987). International Committee on Systematic Bacteriology. Report of the ad hoc committee on reconciliation of approaches to bacterial systematics. Int J Syst Bacteriol 37, 463-464.

Weon, H.-Y., Kim, B.-Y., Joa, J.-H., Son, J.-A., Song, M.-H., Kwon, S.-W., Go, S.-J. \& Yoon, S.-H. (2008). Methylobacterium iners sp. nov. and Methylobacterium aerolatum sp. nov., isolated from air samples in Korea. Int J Syst Evol Microbiol 58, 93-96.

Whittenbury, R., Phillips, K. C. \& Wilkinson, J. F. (1970). Enrichment, isolation and some properties of methane-utilizing bacteria. J Gen Microbiol 61, 205-218. 